\title{
Level of sachet water consumption in Nsukka urban, Enugu State, Nigeria
}

\author{
Ezeokpube, N. D ${ }^{1}$ and Obiora, C. $\mathrm{J}^{2}$ \\ ${ }^{I}$ Department of Geography, University of Nigeria, Nsukka. \\ ${ }^{2}$ Department of Agricultural Economics and Extension, Federal University Oye-Ekiti Nigeria
}

\begin{abstract}
It is a common belief that the consumption of sachet water is high among households in Nigeria. The study sought to determine the level of sachet water consumed in Nsukka urban, Enugu State, Nigeria. A sample of seven hundred and twenty (720) randomly selected respondents was used for the study. Out of the 720 structured questionnaire distributed, only 74\% were completely filled/returned and used for the analysis. Descriptive statistic (percentage) was used for the analysis. The results show that sachet water consumption was high in all the wards in Nsukka urban with University ward ranking highest (72\%). It further shows that students were the highest (61\%) consumers of sachet water. High level consumption of sachet water in the study area invariably will generate high sachet water wastes. The study therefore recommends that appropriate authorities example Enugu State Waste Management Authority (ESWAMA) should provide adequate number of dumpsters at strategic places to ensure proper disposal of the anticipated large quantities of sachet waste that will result from the high level consumption of sachet water. Furthermore, the study recommends that government and private establishments could embark on the recycling of the waste as an economic venture.
\end{abstract}

Keywords: Sachet water, Nsukka urban, Consumption, Enugu State.

\section{Introduction}

The absence of surface water in Nsukka urban have deprived the Nsukka urban dwellers the primary sources of water supplies such as rivers and lakes; which are very important to traditional settlements as a source of water supply [1]. Following the introduction of pipe-borne water in Nsukka urban, domestic water needs of the people were largely met. Unfortunately, most of those pipes laid down to supply water are no longer functional; they are either rusted or broken. This exposed the people to obtaining their domestic water needs from undesirable sources with the attendant problems of incurring water borne diseases like cholera, typhoid, dysentery etc.

Consequently, the introduction of sachet water into the market in Nigeria, including Nsukka urban was well accepted by the people as a reliable means of obtaining potable water, quenching thirst and escaping from water borne diseases. However, after the consumption of the water, the sachet water wastes are disposed indiscriminately at various undesired sites such as along the streets, gutters, motor parks, schools, markets, homes, and venues of social functions etc.; thereby, leaving behind a very unsightly, polluted and filthy environment. They also contribute immensely to a lot of other environmental problems [2].

Sachet water waste disposal is a vast problem that needs to be tackled because of the implications it has on biophysical environment such as soil, vegetation, air, water and on health.

In Uganda, [3] noted that the effects of poor sachet water wastes disposal on the environment lead to loss of soil fertility because they cannot rot and decompose. He was of the view that polythene sachet water has an acidic combination of sulphur-oxide which with time disturbs the chemical formulae of the soils. $\mathrm{He}$ suggested that recollection of these sachet water wastes for recycling, by the producing companies will go a long way in solving these problems. [4] noted that the oxides of carbon, sulphur and nitrogen produced from disposed water sachets cause various health problems such as cancer, carboxyl-haemoglobin, brain damage, dizziness, headache, fatigue, lethargy, respiratory problem and eye irritation. The resulting environmental ills from burning the sachet waste pose extreme health hazards to people (both consumers and non-consumers) exposed to them such conditions according to [5] can precipitate epidemics and national health crises. In Nigeria, [6] noted that the disposal of waste generated from the production and consumption of packaged water including sachet water, constitutes an aspect of health and environmental hazards. She stressed that generally pollution affects not only the polluters but also the non-polluters, that is, it has external effects (externality) on those who are not responsible for the pollution especially during burning.

According to [7] over 70 percent of Nigerian adults drink at least a sachet of water per day resulting in about 50 to 60 million sachet water waste disposed daily across the country. If such quantities of sachet water waste are generated daily, there is need for their proper disposal. Improper disposal of the sachet waste will expose the country to environmental problems on soil, vegetation, air, water and on health. Against this 
backdrop, it becomes pertinent to determine the level of sachet water consumption in Nsukka urban, Enugu State, Nigeria.

\section{Methodology}

The study was conducted in Nsukka urban, Enugu State, Nigeria. Nsukka is one of the major towns in Enugu State of Nigeria, situated towards the northern part of the state. The land surface of Nsukka lies between latitudes $06^{\circ} 18^{\prime} \mathrm{N}$ and $07^{\circ} 06^{\prime} \mathrm{N}$ and longitudes $06^{\circ} 52^{\prime} \mathrm{E}$ and $07^{\circ} 54^{\prime} \mathrm{E}$ (Fig1). Nsukka has a humid (forest) mega thermal climate. But, there is a seasonal drought from November to March, when soil moisture storage is nil. Consequently, the climate is of the tropical wet-and-dry (savanna) type. Atmospheric temperature in Nsukka is high with mean daily minimum temperatures between $21.4^{\circ} \mathrm{C}$ to $25.0^{\circ} \mathrm{C}$ and mean daily maximum temperatures between $28.1^{\circ} \mathrm{C}$ to $34.6^{\circ} \mathrm{C}$, while the mean daily range varies from about $6.6^{\circ} \mathrm{C}$ to $12.2^{\circ} \mathrm{C}$. Nsukka urban is divided into Nru, Nkpunano, Ihe, Owerre, University of Nigeria, Nsukka and Government Reserved Area (GRA) wards (Fig 2). One hundred and twenty (120) respondents were randomly selected from each of the wards giving a total sample size of seven hundred and twenty (720) respondents. Out of the 720 structured questionnaire distributed, only five hundred and thirty-five (i. e. $74 \%$ ) were completely filled/returned and used for the analysis (Table 1). Descriptive statistic (percentage) was used for data analysis and the results were presented in Tables.

\subsection{Level of consumption of water from various sources}

\section{Results And Discussion}

Table 2 shows the level/quantity of water consumed from various sources of drinking water in the different wards in Nsukka urban. The entries show that majority (42\%) of the respondents from Nru ward consumes sachet water, $27 \%$ consumes water from borehole/well. Twenty two percent and $9 \%$ consumed water from pipe borne water and rain water respectively. It also shows that in Owerre ward, majority (51\%) consumes sachet water, $26 \%$ consumes water from borehole/well, $21 \%$ consumes water from pipe borne water whereas only $2 \%$ consumes rain water.

Further, the Table shows that in Ihe ward, $51 \%$ consumes sachet water, $32 \%$ consumes water from borehole/well, $15 \%$ consumes water from pipe borne water while $2 \%$ consumes rain water. In Nkpunano ward, majority (47\%) consumes sachet water, $28 \%$ from borehole/well, $22 \%$ from pipe borne water and $3 \%$ from rain water. In the University ward, majority (72\%) consumes sachet water, $10 \%$ consumes water from borehole/well, $18 \%$ consumes from pipe borne water whereas as none consumed rain water. Sixty three percent consumes sachet water, $29 \%$ consumes water from borehole/well, $8 \%$ consumed water from pipe borne water and none consumed rain water (Table 2).

From the Table it was very clear that in all the wards in Nsukka urban, the level of consumption of sachet water is high. University ward stands out as the highest consumer of sachet water with $72 \%$. This should be expected because they are the most literate in all the wards and may be conscious of the hygienic nature of the water they consume and its source. This study agrees with that of Edoga et al. (2008), which noted that over $70 \%$ of Nigerian adults drink at least a sachet of water per day resulting in about 50 to 60 million sachet water waste disposed. Since it is evident that there is high level consumption of sachet water in the study area, the appropriate agencies/bodies e.g. Enugu State Waste Management Authority (ESWAMA) should make necessary arrangement to provide dumpsters at strategic places so that respondents could dispose the sachet waste properly. If such is not provided, with the high consumption level of sachet water, the streets and drainages in Nsukka urban will soon be littered/filled with the sachet waste.

\subsection{Percentage distribution of respondents using occupation to determine level of consumption of water from various sources}

Table 3 shows level of water consumed from different sources grouping the respondents based on occupation. From the data collected, the students stand out as the highest consumer of sachet water in all the wards of Nsukka urban with 61\%. Twenty eight (28) percent of the students consumed water from borehole/well whereas $11 \%$ consumed from pipe-borne water. Civil servants also exhibited high level of sachet water consumption with 55\%. Twenty five (25) percent and $23 \%$ consumed water from borehole/well and pipe borne water respectively. Among the traders, 53\% consume sachet water because according to them; it is more reliable, portable and affordable; $25 \%$ consume borehole/well water while $16 \%$ and $6 \%$ consume pipe-borne water and rain water respectively. For the artisans, $27 \%$ consume sachet water, $18 \%$ consume from borehole/well, $37 \%$ consume from pipe borne water while $18 \%$ consume rain water.This results shows that students consumes the highest quantities of sachet water. This calls for the distribution of dumpsters in various schools to facilitate proper disposal of the sachet waste. 


\section{Figures And Tables}

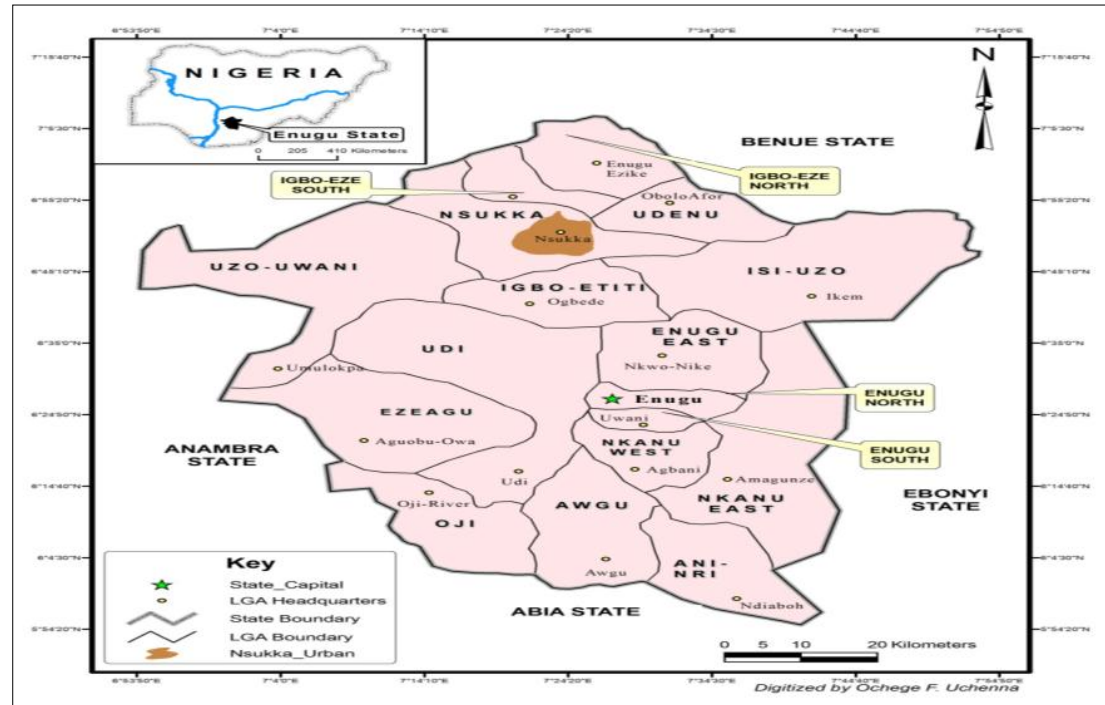

Fig 1: Map of Enugu State showing Nsukka Urban

Source: Department of Geography, University of Nigeria, Nsukka.

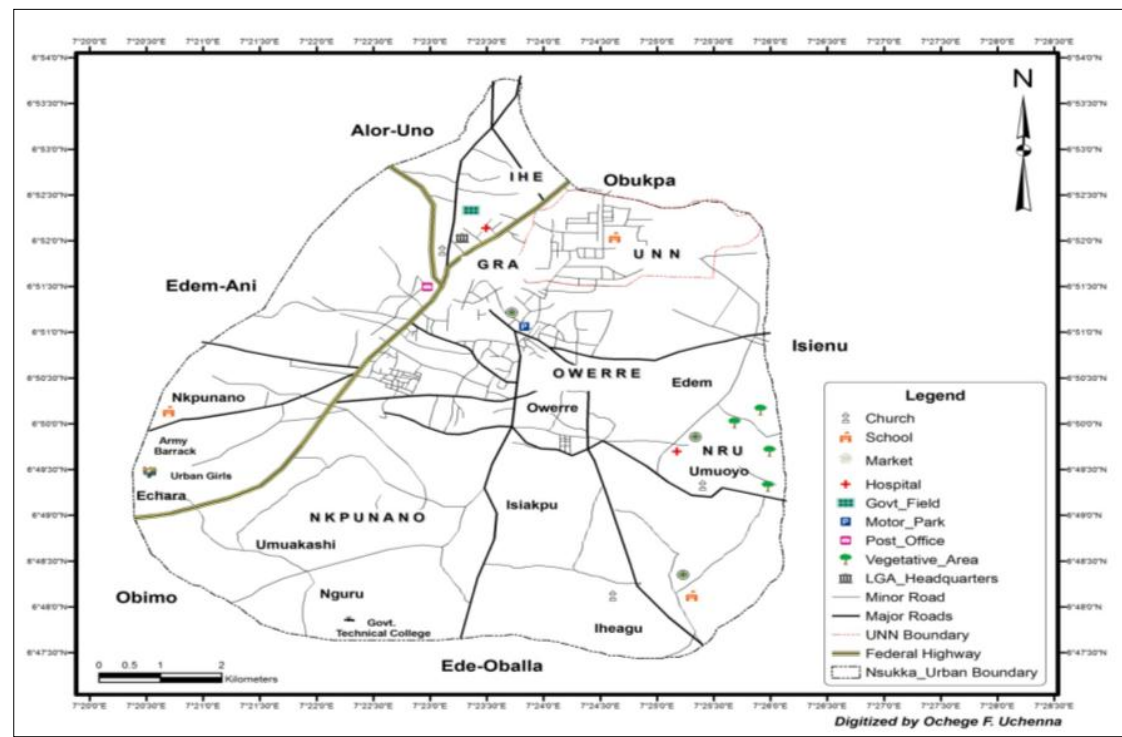

Fig 2: Map showing different wards in Nsukka Urban

Source: Department of Geography, University of Nigeria, Nsukka

Table 1: Copies of questionnaire distributed and returned

\begin{tabular}{|l|c|c|c|}
\hline Wards & No distributed & No returned & \% returned. \\
\hline Nru & 120 & 86 & 71.67 \\
\hline Owerre & 120 & 106 & 88.33 \\
\hline Ihe & 120 & 82 & 68.33 \\
\hline Nkpunano & 120 & 118 & 98.33 \\
\hline University & 120 & 80 & 66.67 \\
\hline GRA & 120 & 63 & 52.50 \\
\hline TOTAL & $\mathbf{7 2 0}$ & $\mathbf{5 3 5}$ & $\mathbf{7 4 . 3 1}$ \\
\hline
\end{tabular}

Source: Field survey 2012 
Table 2: Percentage distribution of respondents on level of water consumed from various sources of drinking water from different wards

\begin{tabular}{|c|c|c|c|c|c|}
\hline Wards & $\begin{array}{l}\text { Sachet } \\
\text { Water }\end{array}$ & Borehole/Well water & $\begin{array}{l}\text { Pipe- } \\
\text { borne } \\
\text { water }\end{array}$ & $\begin{array}{l}\text { Rain } \\
\text { water }\end{array}$ & $\begin{array}{l}\text { Total } \\
\text { respondents }\end{array}$ \\
\hline $\begin{array}{l}\text { Nru } \\
\text { Frequency } \\
\text { Percentage }\end{array}$ & $\begin{array}{c}36 \\
(42 \%)\end{array}$ & $\begin{array}{c}23 \\
(27 \%)\end{array}$ & $\begin{array}{c}19 \\
(22 \%)\end{array}$ & $\begin{array}{c}8 \\
(9 \%)\end{array}$ & 86 \\
\hline $\begin{array}{l}\text { Owerre } \\
\text { Frequency } \\
\text { Percentage }\end{array}$ & $\begin{array}{c}54 \\
(51 \%)\end{array}$ & $\begin{array}{c}28 \\
(26 \%)\end{array}$ & $\begin{array}{c}22 \\
(21 \%)\end{array}$ & $\begin{array}{c}2 \\
(2 \%)\end{array}$ & 106 \\
\hline $\begin{array}{l}\text { Ihe } \\
\text { Frequency } \\
\text { Percentage }\end{array}$ & $\begin{array}{c}42 \\
(51 \%)\end{array}$ & $\begin{array}{c}26 \\
(32 \%)\end{array}$ & $\begin{array}{c}12 \\
(15 \%)\end{array}$ & $\begin{array}{c}2 \\
(2 \%)\end{array}$ & 82 \\
\hline $\begin{array}{l}\text { Nkpunano } \\
\text { Frequency } \\
\text { Percentage }\end{array}$ & $\begin{array}{c}56 \\
(47 \%)\end{array}$ & $\begin{array}{c}33 \\
(28 \%)\end{array}$ & $\begin{array}{c}26 \\
(22 \%)\end{array}$ & $\begin{array}{c}3 \\
(3 \%)\end{array}$ & 118 \\
\hline $\begin{array}{l}\text { University } \\
\text { Frequency } \\
\text { Percentage }\end{array}$ & $\begin{array}{c}58 \\
(72 \%)\end{array}$ & $\begin{array}{c}8 \\
(10 \%)\end{array}$ & $\begin{array}{c}14 \\
(18 \%)\end{array}$ & (0\%) & 80 \\
\hline $\begin{array}{l}\text { GRA } \\
\text { Frequency } \\
\text { Percentage }\end{array}$ & $\begin{array}{c}40 \\
(63 \%)\end{array}$ & $\begin{array}{c}18 \\
(29 \%)\end{array}$ & $\begin{array}{c}5 \\
(8 \%)\end{array}$ & - & 63 \\
\hline TOTAL & $\begin{array}{c}286 \\
(53 \%)\end{array}$ & $\begin{array}{c}136 \\
(25 \%)\end{array}$ & $\begin{array}{c}98 \\
(18 \%)\end{array}$ & $\begin{array}{c}15 \\
(3 \%)\end{array}$ & $\begin{array}{c}535 \\
(100)\end{array}$ \\
\hline
\end{tabular}

Source: Field work, 2012.

Table 3: Using occupation to determine level of consumption of water from various sources.

\begin{tabular}{|c|c|c|c|c|c|}
\hline Occupation & $\begin{array}{l}\text { Sachet } \\
\text { water }\end{array}$ & $\begin{array}{l}\text { Borehole/ } \\
\text { well }\end{array}$ & $\begin{array}{l}\text { Pipe-borne } \\
\text { water }\end{array}$ & Rain water & $\begin{array}{c}\text { Total } \\
\text { respondents }\end{array}$ \\
\hline $\begin{array}{l}\text { Students } \\
\text { Frequency } \\
\text { Percentage }\end{array}$ & $\begin{array}{c}109 \\
(61 \%)\end{array}$ & $\begin{array}{c}51 \\
(28 \%)\end{array}$ & $\begin{array}{c}20 \\
(11 \%)\end{array}$ & $\begin{array}{c}- \\
(0 \%)\end{array}$ & 180 \\
\hline $\begin{array}{l}\text { Civil-servants } \\
\text { Frequency } \\
\text { Percentage }\end{array}$ & $\begin{array}{c}98 \\
(55 \%)\end{array}$ & $\begin{array}{c}46 \\
(25 \%)\end{array}$ & $\begin{array}{c}43 \\
(23 \%)\end{array}$ & $\begin{array}{c}- \\
(0 \%)\end{array}$ & 187 \\
\hline $\begin{array}{l}\text { Traders } \\
\text { Frequency } \\
\text { Percentage }\end{array}$ & $\begin{array}{c}56 \\
(53 \%)\end{array}$ & $\begin{array}{c}26 \\
(25 \%)\end{array}$ & $\begin{array}{c}17 \\
(16 \%)\end{array}$ & $\begin{array}{c}6 \\
(6 \%)\end{array}$ & 105 \\
\hline $\begin{array}{l}\text { Artisans } \\
\text { Frequency } \\
\text { Percentage }\end{array}$ & $\begin{array}{c}13 \\
(27 \%)\end{array}$ & $\begin{array}{c}9 \\
(18 \%)\end{array}$ & $\begin{array}{c}18 \\
(37 \%)\end{array}$ & $\begin{array}{c}9 \\
(18 \%)\end{array}$ & 49 \\
\hline $\begin{array}{l}\text { Others } \\
\text { Frequency } \\
\text { Percentage }\end{array}$ & $\begin{array}{c}10 \\
(7 \%)\end{array}$ & $\begin{array}{c}4 \\
(29 \%)\end{array}$ & $(0 \%)$ & $(0 \%)$ & 14 \\
\hline TOTAL & $\begin{array}{c}286 \\
(53 \%)\end{array}$ & $\begin{array}{c}136 \\
(25 \%)\end{array}$ & $\begin{array}{c}98 \\
(18 \%)\end{array}$ & $\begin{array}{c}15 \\
(3 \%)\end{array}$ & $\begin{array}{c}535 \\
(100)\end{array}$ \\
\hline
\end{tabular}

Source: Field work; 2012

\section{Conclusion}

The study investigated the level of consumption of sachet water in Nsukka Urban. One hundred and twenty (120) respondents were randomly selected from each of the wards giving a total sample size of seven hundred and twenty (720) respondents. Out of the 720 structured questionnaire distributed, only five hundred and thirty-five (i.e.74\%) were completely filled/returned and used for the analysis. Results show high level consumption of sachet water in all the wards with University ward ranking highest (72\%). It further shows that students were the highest consumers of sachet water $(61 \%)$. 
High level consumption of sachet water in the study area invariably will lead to the high generation of sachet water wastes. The study therefore recommends that appropriate authorities example Enugu State Waste Management Authority should provide adequate number of dumpsters at strategic places to ensure proper disposal of the anticipated large quantities of sachet waste that will result from the high level consumption of sachet water.

\section{References}

[1]. Ezeokpube, N. D. (2013). Environmental problems of sachet water waste disposal in Nsukka urban, Enugu State, Nigeria. M.Sc, Thesis, Department of Geography, University of Nigeria, Nsukka.

[2]. Ezeokpube, N. D, C. J. Obiora and P.O. Phil-Eze, 2014. Environmental problems of sachet water waste disposal in Nsukka urban, Enugu State, Nigeria. Civil and Environmental Research, 6(1): 105-113.

[3]. Mutagamba, M. 2007. Polythene waste disposal Uganda. The New Vision Uganda Leading website Newspaper. August $11,2007$.

[4]. Babatunde, A.M. and M. I Biala, 2010. Externality effects of sachet water consumption and the choice of policy instrument in Nigeria: Evidence from Kwara state. Journal article of Economics, 1 (2): pp. 113-131.

[5]. Adenuga, A. O, K. Ogujiuba and F. K Ohuche, 2006. Sustainability of the environment and water pollution in Nigeria: problems, management and policy option. Global Journal of Environmental Sciences, 5 (1) 49-59.

[6]. Akunyili, D. N. 2003. The role of pure water and bottled water manufacturers in Nigeria. Paper presented at the 29th Water Engineering and Development Centre International Conference in Abuja, Nigeria.

[7]. Edoga, M.O., L. I. Onyeji and O. O Oguntosin, 2008. Achieving vision 20:2020 through waste produce candle. Journal of Engineering and Applied Sciences, 3(8): 642-646. 